\title{
First report of Ditylenchus gallaeformans in Miconia albicans from the Brazilian Cerrado, State of Goiás
}

\section{Primeiro relato da ocorrência de Ditylenchus gallaeformans em Miconia albicans no Cerrado Brasileiro, no Estado de Goiás}

\author{
Rodrigo Vieira da Silva ${ }^{1 *}$; Dalila Sêni de Jesus ${ }^{2}$; Brenda Ventura de Lima e Silva ${ }^{3}$; \\ Bruno Eduardo Cardozo de Miranda ${ }^{4}$; João Pedro Elias Gondim ${ }^{5}$
}

\begin{abstract}
Miconia albicans (Melastomataceae), whose common name is canela-de-velha, is a native plant of the tropical region that is abundant in the Cerrado biome. A nematode species was found parasitizing $M$. albicans, causing severe deformation and gall-like structures on the infected leaves and inflorescences. Morphological, morphometric and molecular characterizations identified the nematode as Ditylenchus gallaeformans. This nematode has great potential as a biocontrol agent of plants in the family Melastomataceae, which are invasive weeds in ecosystems of the Pacific Islands. This is the first report of D. gallaeformans parasitizing M. albicans in the Cerrado of the state of Goiás.
\end{abstract}

Key words: Biological control. Melastomataceae. Phytonematode.

\section{Resumo}

Miconia albicans (Melastomataceae), nome popular: canela-de-velha, é uma espécie vegetal nativa das regiões tropicais e abundante no bioma cerrado. Uma espécie de nematoide foi encontrada parasitando M. albicans causando severas deformações e galhas em folhas e inflorescências. Caracterizações morfológicas, morfométricas e moleculares foram realizadas e o nematoide foi identificado como sendo Ditylenchus gallaeformans. Esse nematoide tem grande potencial para o uso no controle biológico de espécies vegetais da família Melastomataceae que são invasoras em ecossistemas das ilhas do Pacífico. Este é o primeiro relato de $D$. gallaeformans parasitando $M$. albicans no cerrado goiano.

Palavras-chave: Controle biológico. Melastomataceae. Fitonematoide.

\footnotetext{
${ }^{1}$ Prof. Dr., Programa de Pós-Graduação em Olericultura, Instituto Federal Goiano, IF Goiano, Campus Morrinhos, Morrinhos, GO, Brasil. E-mail: rodrigo.silva@ifgoiano.edu.br

${ }^{2}$ Eng $^{\mathrm{a}}, \mathrm{Agr}^{\mathrm{a}}, \mathrm{Dr}^{\mathrm{a}}$, Bolsista PNPD/CAPES, Dept ${ }^{\mathrm{o}}$ de Fitopatologia, Universidade Federal de Viçosa, UFV, Viçosa, MG, Brasil. E-mail: dalilaseni@yahoo.com.br

${ }^{3}$ Eng $^{\mathrm{a}}$, Agra , M.e, IF Goiano, Campus Morrinhos, Morrinhos, GO, Brasil. E-mail: brenda.ventura@ifgoiano.edu.br

${ }^{4}$ Agr $^{\circ}$, Dr., Bolsista DCR, CNPq/FAPEG, IF Goiano, Campus Morrinhos, Morrinhos, GO, Brasil. E-mail: becmiranda@yahoo. com.br

${ }^{5}$ Discente do Curso de Graduação em Agronomia, Bolsista de Iniciação Científica PIBIC CNPq, Dept ${ }^{\circ}$ de Agronomia, IF Goiano, Campus Morrinhos, Morrinhos, GO, Brasil. E-mail: joaopedro.pba@hotmail.com

* Author for correspondence
} 
Phytonematodes are mainly known for their ability to induce changes in their hosts that cause serious damage to crops of economic importance worldwide (JASMER et al., 2003). The genus Ditylenchus Filipjev, is composed of approximately 60 species, of which four are economically important: (Ditylenchus dipsaci (Kuhn) Filipjev, Ditylenchus destructor Thorne, Ditylenchus angustus (Butler) Filipjev and Ditylenchus africanus Wendt, Swart, Vrain and Webster) (CARES; TENENTE, 2007). Despite of some Ditylenchus species are harmful to agricultural crops, two species, D. drepanocercus Goodey, and D. gallaeformans Oliveira have been investigated as potencial biocontrol agents of invaders plants belonging to Melastomataceae family in the Pacific islands (SEIXAS et al., 2004; OLIVEIRA et al., 2013).

The family Melastomataceae is composed of more than 4000 species that are distributed in the tropical and subtropical regions of the world (REIS et al., 2005). Of the known species, approximately one-quarter belong to the genus Miconia Ruiz \& Pavon, which is one of the largest of the Neotropical genera, consisting of more than 1,000 species that produce large amounts of fruits consumed by wildlife. Therefore, plants of the genus Miconia are important for the conservation of forest fragments (HIGUCHI et al., 2011). On the other hand, Melastomataceae is one of the most damaging and invasive families of weeds in Hawaii, invading spaces before occupied by native species, threatening flora and fauna of these regions. Of the 15 melastome species naturalized in the Hawaiian Islands 9 have been declared Noxious Weeds, the worst being Clidemia hirta, Tibouchina herbacea, Oxyspora paniculata, and Miconia calvescens (MEDEIROS et al., 1997). The biological control of these invasive weeds is the only environmentally viable option to curb the spread of the pest.

In Brazil, melastome species are native and widespread in different biomes as Amazonian, Atlantic Rainforest and Cerrado. Miconia albicans (Swartz) Triana, whose common name is canela- de-velha, is an arboreal species that is primarily distributed in the tropical regions of the world. This species, is very abundant in the Brazilian flora, mainly in the Cerrado biome (REIS et al., 2005). In this biome, $M$. albicans plays an important role because of its wide distribution and its biological interactions (GOLDENBERG; SHEPHERD, 1998). The flowers of M. albicans, which are whitish, small, and odorless, do not produce pollen (GOLDENBERG; SHEPHERD, 1998). Its leaves are produced in both the rainy and dry seasons throughout the entire year. The fruit of $M$. albicans are small but numerous and are mainly consumed by native birds; therefore, the species has great potential for use in the recovery of degraded areas (GOLDENBERG; SHEPHERD, 1998).

There are few studies available in the literature concerning the phytosanitary aspects of M. albicans, especially regarding phytonematodes. Viana et al. (2013) and Silveira and Oliveira (2013) reported symptoms caused by Ditylenchus sp.; however, the identification of the species of this nematode was not performed.

In 2013, Miconia sp. samples showing leaf deformations and gall-like structures on their leaves, stems and inflorescences (Figure 1A-E) were collected in the Mata do Cerrado Reserve (Reserva da Mata do Cerrado) of the Goiano Federal Institute (Instituto Federal Goiano - IF Goiano), Morrinhos campus, located in the municipality of Morrinhos in the southern state of Goiás. Samples of Miconia sp. were sent to the Herbarium Uberlandense at the Federal University of Uberlândia (Universidade Federal de Uberlândia - UFU) within the Institute of Biology (Instituto de Biologia), Umuarama campus, where they were identified as M. albicans.

Detailed analysis of the M. albicans samples showed that the symptoms were associated with a nematode species that is described in the current study based on morphological, morphometric and molecular characters. The nematode extraction was performed from symptomatic tissues according 
to Oliveira et al. (2013). Infected leaves and inflorescences of $M$. albicans were collected in an easily accessible location in the vicinity of the forest of the IF Goiano, Morrinhos campus, municipality of Morrinhos, state of Goiás. The suspension of each sample recovered from the 500-mesh sieve was observed under a stereoscopic microscope to detect the presence of nematodes, and the species identification of each nematode was subsequently performed with the aid of a light microscope.

Additionally, nematodes isolated from leaves and inflorescences, naturally infected in the field, were inoculated in healthy plants of $M$. albicans to confirm their pathogenicity to this plant species. In the laboratory, the galls were removed, crushed for $20 \mathrm{~s}$ in a blender and then poured through 60and 500-mesh sieves to separate the nematodes. The suspension obtained from the 500-mesh sieve was left in a Baermann funnel for $24 \mathrm{~h}$ to separate the live nematodes from the dead. The suspension was calibrated to 1000 nematodes $/ \mathrm{mL}$ with the aid of a Peters chamber. Six M. albicans plants were inoculated with $2 \mathrm{~mL}$ of the inoculum containing the nematodes. The inoculations were performed with the aid of a pipette by depositing the suspension containing juveniles (J2) of D. gallaeformans on cotton pieces positioned in leaf primordia. Then, the inoculated plants were kept for $48 \mathrm{~h}$ in a humid growth chamber at $25^{\circ} \mathrm{C}$ on a $12 \mathrm{~h}$ photoperiod. Later, the plants were transferred to a greenhouse at the IF Goiano, Morrinhos campus. The development of symptoms was observed weekly during 150 days.

Some samples were submitted to Nematology laboratory at UniversidadeFederal de Viçosa, Viçosa, $\mathrm{MG}$, to morphometric and molecular analyses. Adult nematodes of both sexes were mounted on permanent slides for specimen identification. The morphological examination and morphometric measurements (Table 1) of our population were similar to those provided in the original description of D. gallaeformans (OLIVEIRA et al., 2013).

The extraction of genomic DNA was performed as proposed by Holterman et al. (2006). Ditylenchus specimens were extracted from the leaf galls and the inflorescences of $M$. albicans by continuous aeration for $24 \mathrm{~h}$. Ten females were transferred to microcentrifuge tubes $(0.2-\mu \mathrm{L})$ containing $50 \mu \mathrm{L}$ of Holterman lysis buffer (HLB). To optimize the DNA extraction, the selected females were cut into three parts (using a needle on a glass slide containing a drop of HLB) and transfer to the microcentrifuge tubes. Then, the tubes were placed in a thermocycler at $65{ }^{\circ} \mathrm{C}$ for $2 \mathrm{~h}$, followed by $5 \mathrm{~min}$ incubation at $99^{\circ} \mathrm{C}$. The genomic DNA extracted was then used for the amplification of ribosomal DNA (rDNA) by PCR.

For the rDNA amplification, a combination of universal primers that amplify the final portion of the $18 \mathrm{~S}$ and ITS-1 regions was used: SSUF02 (5' -GGAAGGGCACCACCAGGAGTGG-3' (OLIVEIRA et al., 2004) and rDNA1.58S (5'-ACGAGCCGAGTGATCCACCG-3'). The PCRs were performed in a total reaction volume of $50 \mu \mathrm{L}$ containing $1 \mu \mathrm{L}$ of total DNA, 1.5 units of DNA polymerase (Platinum Taq, Invitrogen Corp., Carlsbad, CA, USA), 1X PCR buffer (20 $\mathrm{mM}$ Tris- $\mathrm{HCl}[\mathrm{pH} 8.4]$ and $500 \mathrm{mM} \mathrm{KCl}), 1.5 \mathrm{mM}$ $\mathrm{MgCl} 2,200 \mu \mathrm{M}$ of each dNTP, $0.2 \mu \mathrm{M}$ of each primer and Milli-Q water to complete the reaction volume. A reaction without DNA was included as a negative control. The amplification conditions were as follows: initial denaturation at $94{ }^{\circ} \mathrm{C}$ for $1 \mathrm{~min}$ followed by 40 cycles of denaturation $(30 \mathrm{~s}$ at 94 $\left.{ }^{\circ} \mathrm{C}\right)$, primer annealing $\left(30 \mathrm{~s}\right.$ at $\left.61^{\circ} \mathrm{C}\right)$, extension $(1$ min at $72{ }^{\circ} \mathrm{C}$ ) and final extension for $10 \mathrm{~min}$ at 72 ${ }^{\circ} \mathrm{C}$. After the amplification, $5 \mu \mathrm{L}$ of the PCR product was used for electrophoresis in 0.5X TAE buffer on a $0.8 \%$ agarose gel stained with GelRedTM (Biotium, Hayward, CA, USA). The amplification result was compared with a $1-\mathrm{kb}$ molecular weight marker (Promega, Madison, WI, USA), and the gel was visualized and photographed in a UV transilluminator (Figure 1F). The PCR products were purified using the Wizard ${ }^{\circledR}$ SV Gel and PCR Clean-Up System (Promega) and the sequencing was performed by Macrogen (Seoul, Republic of Korea). 
Table 1. Morphometrics of females and males of Ditylenchus gallaeformans parasitizing Miconia albicans. All measurements are in $\mu \mathrm{m}$ and in the form: mean \pm s.d. (range).

\begin{tabular}{|c|c|c|}
\hline Character & Females & Males \\
\hline $\mathrm{n}$ & 8 & 6 \\
\hline \multirow[t]{2}{*}{ Body length } & $578.7 \pm 35.4$ & $548.5 \pm 33.8$ \\
\hline & $(521.0-616.8)$ & $(497.9-579.3)$ \\
\hline \multirow[t]{2}{*}{$a^{1}$} & $33.9 \pm 4.5$ & $34.2 \pm 2.8$ \\
\hline & $(26.6-38.8)$ & $(30.0-37.6)$ \\
\hline \multirow[t]{2}{*}{$c^{2}$} & $14.5 \pm 2.6$ & $16.3 \pm 2.2$ \\
\hline & $(11.8-20.1)$ & $(13.9-19.2)$ \\
\hline \multirow[t]{2}{*}{$c^{3}$} & $3.9 \pm 0.4$ & $2.4 \pm 0.3$ \\
\hline & $(3.3-4.4)$ & $(2.1-3.0)$ \\
\hline \multirow[t]{2}{*}{ Stylet } & $7.6 \pm 0.4$ & $7.9 \pm 0.2$ \\
\hline & $(7.0-8.1)$ & $(7.7-8.1)$ \\
\hline \multirow[t]{2}{*}{ Median bulb height } & $14.2 \pm 2.2$ & $16.0 \pm 1.8$ \\
\hline & $(10.7-18.6)$ & $(13.8-17.7)$ \\
\hline \multirow[t]{2}{*}{ Median bulb diameter } & $7.9 \pm 0.6$ & $8.6 \pm 0.5$ \\
\hline & $(7.0-9.0)$ & $(8.0-9.3)$ \\
\hline \multirow[t]{2}{*}{ Head to cardia } & $133.9 \pm 5.8$ & $134.1 \pm 5.8$ \\
\hline & $(124.8-140.3)$ & $(127.4-140.7)$ \\
\hline \multirow[t]{2}{*}{ Anal body diameter } & $10.7 \pm 1.2$ & $14.1 \pm 0.6$ \\
\hline & $(8.8-12.3)$ & $(13.3-14.6)$ \\
\hline \multirow[t]{2}{*}{ Tail length } & $41.4 \pm 6.2$ & $34.1 \pm 4.8$ \\
\hline & $(30.7-49.8)$ & $(27.6-41.1)$ \\
\hline \multirow[t]{2}{*}{ PUS/VA $\%{ }^{4}$} & $28.1 \pm 7.3$ & $\ldots$ \\
\hline & $(20.1-39.7)$ & \\
\hline \multirow[t]{2}{*}{$\mathrm{V} \%{ }^{5}$} & $74.9 \pm 1.7$ & $\ldots$ \\
\hline & $(72.3-78.3)$ & \\
\hline \multirow[t]{2}{*}{ Bursa } & $\ldots$ & $50.7 \pm 5.4$ \\
\hline & & $(43.2-56.9)$ \\
\hline \multirow[t]{2}{*}{ Spicules } & $\ldots$ & $18.0 \pm 2.6$ \\
\hline & & $(13.4-19.8)$ \\
\hline \multirow[t]{2}{*}{ Gubernaculum } & $\ldots$ & $7.0 \pm 0.3$ \\
\hline & & $(6.7-7.3)$ \\
\hline
\end{tabular}

${ }^{1}$ Ratio body length/largest body diameter. ${ }^{2}$ The ratio of the length of the body and tail. ${ }^{3}$ Tail length divided by body diameter at the anus. ${ }^{4}$ Post vulval sac length as a percentage of vulva to anus distance. ${ }^{5}$ Position of vulva from anterior end expressed as a percentage of body length.

The sequence obtained was edited in the BioEdit Sequence Alignment Editor software, which is available at http://www.mbio.ncsu.edu/bioedit/ page 2.html and deposited at the GenBank under the accession number KM274867. After the sequence was edited, the ITS-1 region of the rDNA was obtained and compared with sequences deposited in GenBank, which verified 99\% identity with the sequences of D. gallaeformans. Therefore, the morphology of the specimens collected in the current study together with the high homology of the aforementioned ITS-1 region with the $D$. gallaeformans sequences deposited at GenBank confirms the identity of the specimens collected in the current study.

Regarding the pathogenicity test, the symptoms caused by D. gallaeformans in M. albicans after 30 days of inoculation were similar to those observed in the field and described by Oliveira et al. (2013). 
There was severe leaf distortion and variously sized, gall-like formations on the adaxial and abaxial and the petioles, in addition to the formation of surfaces, both on the lamina and near the main vein

Figure 1. A. Miconia albicans in a Cerrado reserve area of the IF Goiano, Morrinhos campus. B. Leaves with gall-like structures caused by Ditylenchus gallaeformans. C. Inflorescence showing severe symptoms of galls. D. Development of numerous galls caused by D. gallaeformans on the abaxial surface of leaves of M. albicanss. E. Detail of galls on the abaxial surface of leaves of $M$. albicans. F. Agarose gel (0.7\%) with the amplicon of D. gallaeformans obtained by PCR. Lanes from the left to the right: marker (1 Kb Promega); control without DNA; amplicon obtained using SSUF02 and rDNA1.58S primers.
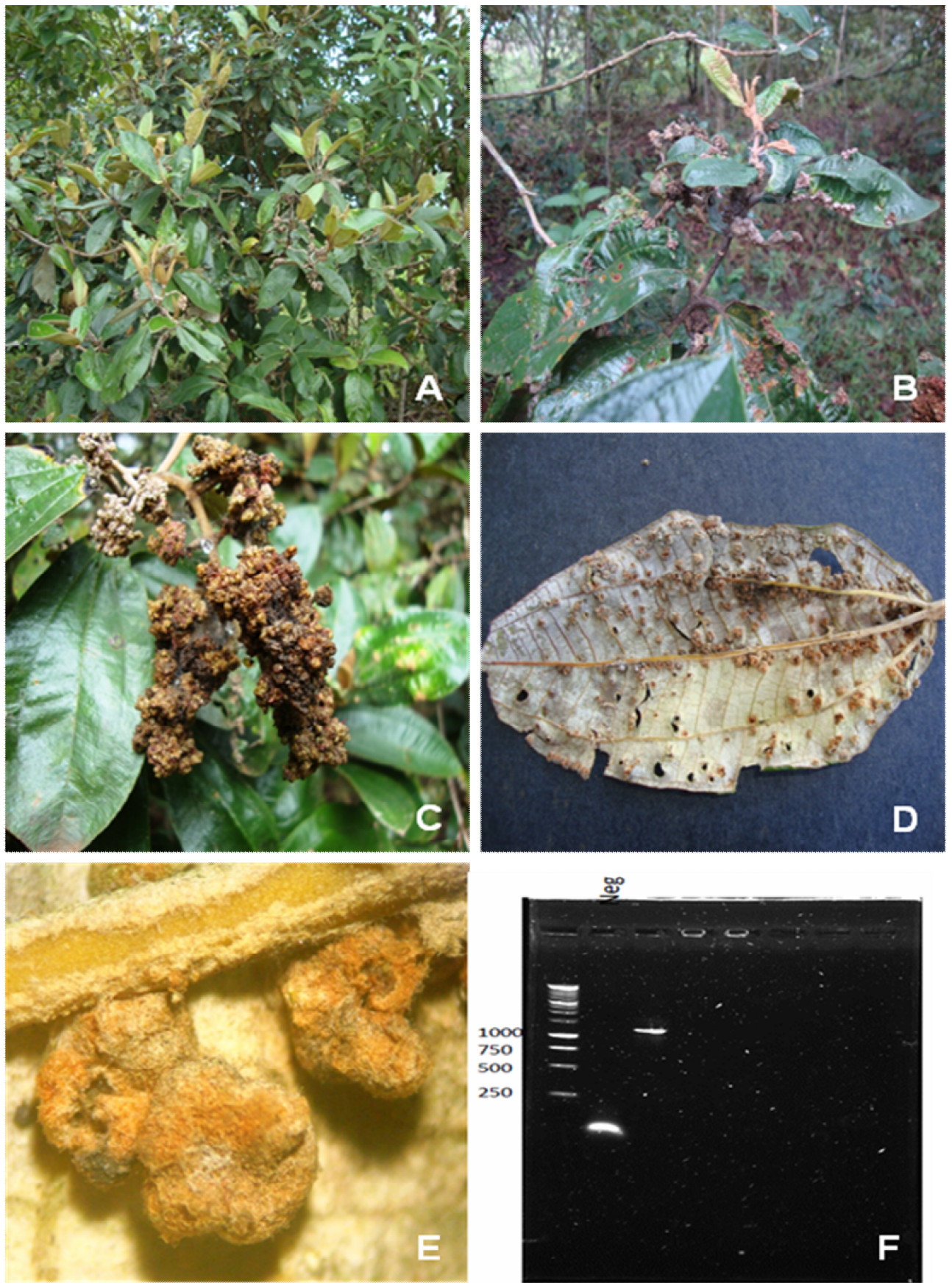
There are several studies on the biological control of invasive plants using phytopathogens, either through the survey or the release and monitoring of these organisms in the environment; however, experiments using fungi are prevalent. Surveys with nematodes are scarce and are often older. $D$. gallaeformans is probably widely distributed in Brazil and Costa Rica, and this nematode species was first described by Oliveira et al. (2013) causing severe symptoms that consisted of the formation of gall-like structures on the leaves, stems and inflorescences of invasive weeds in the family Melastomataceae. These plants were introduced to the Pacific Islands and became dominant species, developing into a serious threat to the sensitive ecosystems of that region.

Once management through mowing and herbicide application is operational, economic and environmentally unfeasible, the biological control of species in the family Melastomataceae using D. gallaeformans appears to be a less aggressive and highly specific management alternative. The symptoms and the density of the galls that were observed on $M$. albicans inflorescences indicate that $D$. gallaeformans can quite effectively control pest plants in the family Melastomataceae. Viana et al. (2013) verified that M. albicans infected with Ditylenchus sp. has not only significantly shorter inflorescences and less fruit production than specimens not infected with the nematode but also severely reduced seed viability. The current study is the first report of D. gallaeformans in the Cerrado biome of the state of Goiás that was previously reported in Minas Gerais State (OLIVEIRA et al., 2013).

There are not many reports of geographical distribution of D. gallaeformans so far, since it is a species so recently described. Ditylenchus gallaeformans have been reported in Costa Rica (DIETRICH, 2006), Hawaii (OLIVEIRA et al., 2013) and Venezuela (MORALES-MONTERO et al., 2013) attacking Miconia spp. In Brazil, there is evidence that this nematode is probably widespread in rainforest areas in the state of Rio de Janeiro and Minas Gerais (and Cerrado vegetation) (R.D.L. OLIVEIRA, personal communication). In Pernambuco state, at the northeastern region of Brazil, Ditylenchus sp. was reported in M. prasina (SANTOS et al., 2012). However, up to now, $D$. gallaeformans has not been reported in the state of Goiás, Cerrado biome.

\section{Acknowledgments}

The authors thank Professors Rosana Romero (Herbarium Uberlandense, UFU) for identification of the samples of Miconia spp. and Rosângela D'arc de Lima Oliveira (Federal University of Viçosa Universidade Federal de Viçosa) for allowing the use of her laboratory for the taxonomy studies.

\section{References}

CARES, J. E.; TENENTE, R. C. V. Taxonomia de nematoides de sementes, bulbos e caules - parte I. Revisão Anual de Patologia de Plantas, Passo Fundo, v. 15, n. 1, p. 69-98, 2007.

DIETRICH, A. Evaluation of pathogens from Costa Rica for biological control of Miconia calvescens in Hawaii. Hannover: Diplomarbeit im Studiengang Biologie, LeibnizUniversität Hannover: Institut für Pflanzenkrankheiten, 2006. 115 p.

GOLDENBERG, R.; SHEPHERD, G. J. Studies on the reproductive biology of Melastomataceae in cerrado vegetation. Plant Systematic and Evolution, Vienna, v. 211, n. 1, p. 13-29, 1998.

HIGUCHI, P.; SILVA, A. C.; VAN DEN BERG, E.; PIFANO, D. S. Associações espaciais entre indivíduos de diferentes espécies de Miconia spp. Ruiz \& Pav. (Melastomataceae). Revista Árvore, Viçosa, MG, v. 35. n. 3, p. 381-389, 2011.

HOLTERMAN, M.; VAND DER WURFF, A.; VAN DER ELSEN, S.; VAN MEGEN, H. ; BONGERS, T.; HOLOVACHOV, O.; BAKKER, J.; HELDER, J. Phylum-wide analysis of SSU rDNA reveals deep phylogenetic relationships among nematodes and accelerated evolution toward Crown Clades. Molecular Biology and Evolution, Oxford, v. 23, n. 9, p. 1792-1800, 2006. 
JASMER, D. P.; GOVERSE, A.; SMANT, G. Parasitic nematode interaction with mammals and plants. Annual Review Phytopathology, Palo Alto, v. 41, n. 1, p. 245$270,2003$.

MEDEIROS, A. C.; LOOPE, L. L.; CONANT, P.; MCELVANEY, S. Status, ecology, and management of the invasive plant, Miconia calvescens DC (Melastomataceae) in the Hawaiian Islands. Bishop Museum Occasional Papers, Honolulu, v. 48, n. 1, p. 2336, 1997.

MORALES-MONTERO, P.; FLORES, S.; SUBBOTIN, S. A.; SAN-BLAS, E. First report of Ditylenchus gallaeformans (Tylenchida: Anguinidae) inducing galls on Clidemia fendleri (Melastomataceae) from Venezuela. Nematropica, Lakeland, v. 43, n. 2, p. 241-246, 2013.

OLIVEIRA, C. M. G.; HÜBSCHEN, J.; BROWN, D. J. F.; FERRAZ, L. C. C. B.; WRIGHT, F.; NEILSON, R. Phylogenetic relationships among Xiphinema and Xiphidorus nematode species from Brazil inferred from 18S rDNA sequences. Journal of Nematology, Hanover, v. 36, n. 2, p. 153-159, 2004.

OLIVEIRA, R. D. L; SANTIN, A. M.; SENI, D. J.; DIETRICH, A.; SALAZAR, L. A.; SUBBOTIN, S. A.; MUNDO-OCAMPO, M.; GOLDENBERG, R.; BARRETO, R. W. Ditylenchus gallaeformans sp. n. (Tylenchida: Anguinidae) - a neotropical nematode with biocontrol potential against weedy Melastomataceae. Nematology, Leiden, v. 15, n. 2, p. 179-196, 2013.
REIS, C.; BIERAS, A. C.; SAJO, M. G. Anatomia foliar de Melastomataceae do cerrado do Estado de São Paulo. Brazilian Journal of Botany, São Paulo, v. 28, n. 3, p. 451-466, 2005.

SANTOS, J. C.; SANTOS, C. I. R.; CARES, J. E.; ALMEIDA-CORTEZ, J. S. Impact of nematode-induced galls on Miconia prasina (Sw.) DC (Melastomataceae) traits in the Atlantic forest of northeastern Brazil. Journal of Plant Interactions, London, v. 7, n. 3, p. 197-203, 2012.

SEIXAS, C. D. S.; BARRETO, R. W.; FREITAS, L. G.; MAFFIA, L. A.; MONTEIRO, F. T. Ditylenchus drepanocercus (Nematoda), a potential biological control agent for Miconia calvescens (Melastomataceae): hostspecificity and epidemiology. Biological Control, San Diego, v. 31, n. 1, p. 29-37, 2004.

SILVEIRA, F. A. O.; OLIVEIRA, E. G. Does plant architectural complexity increase with increasing habitat complexity? A test with a pioneer shrub in the Brazilian Cerrado. Brazilian Journal of Biology, São Carlos, v. 73, n. 2, p. 271-277, 2013.

VIANA, L. R.; VIEIRA, F. A. O; SANTOS, J. C.; ROSA, L. H.; CARES, J. E.; CAFÉ FILHO, A. C.; FERNANDES, G. W. Nematode-induced galls in Miconia albicans: effect of host plant density and correlations with performance. Plant Species Biology, Hirosawa, v. 28, n. 1, p. 63-69, 2013. 
